DOI https://doi.org/10.30525/978-9934-588-80-8-2.30

\title{
ФОРМУВАННЯ ОСНОВ ЗДОРОВОГО СПОСОБУ ЖИТТЯ ДІТЕЙ ДОШКІЛЬНОГО ВІКУ В СИСТЕМІ «ЗАКЛАД ДОШКІЛЬНОЇ ОСВІТИ - РОДИНА»
}

\author{
Труш Н. В. \\ кандидат наук з фізичного виховання та спорту, \\ дочент кафедри професійної освіти та інновачійних технологій \\ Інституту післядипломної освіти та довузівської підготовки \\ ДВНЗ «Прикарпатський національний університет \\ імені Василя Стефаника» \\ м. Івано-Франківськ, Україна
}

Людське життя є найвищою суспільною цінністю, а здоров'я кожного - складовою суспільного багатства, отож формування, збереження та зміцнення здоров'я дитини вважаємо обов'язком кожної матері, батька, педагога перед дитиною, родиною та суспільством загалом.

Метою статті $\epsilon$ визначення впливу способу життя дитини на іiі здоров'я та самопочуття. Здоров'я людини залежить від тієї спадкової генетики, яку отримує немовля ще при народженні, від середовища, в якому зростає і перебуває впродовж життя, від рівня медичного обслуговування та від способу життя, який кожна людина свідомо обирає для себе сама.

Щодо дітей дошкільного віку можна визначити такі параметри здорового способу життя: додержання розпорядку дня, належне оволодіння культурно-гігієнічними навичками та їх щоденне застосування, раціональне харчування та культура споживання їжі, руховий та повітряний режим, режим активної діяльності та відпочинку, профілактичні заходи задля збереження здоров'я, душевний комфорт.

Людина народжується для щасливого повноцінного життя, проте не завжди може насолоджуватися ним повною мірою. Аналізуючи проблеми здоров'я, науковці стверджують, що незадовільний стан здоров'я людства пов'язаний з трьома пороками, які притаманні стилю життя людини початку XXI століття, а саме: накопичення негативних емоцій, переїдання та недостатня рухова активність.

Нині набуває особливої вагомості питання формування основ культури здоров'я людини 3 раннього віку. Лише навчивши дітей турбуватися про здоров'я, власними силами його зміцнювати та 
підтримувати високу працездатність організму, дотримуватися безпечних умов життєдіяльності, можна поліпшити стан здоров'я нації.

Крізь призму валеологічної культури здоров'я розглядаємо як інтегративну якість повноцінного людського буття. В науковій та публіцистичній літературі здоров'я характеризують як стан і позицію людини щодо себе, інших людей, довкілля та Космосу впродовж усього життя.

Доцільно починати формування основ здорового способу життя ще 3 раннього дитинства, адже цей період $\epsilon$ найсприятливішим для оволодіння основними знаннями і навичками 3 охорони здоров'я, які згодом перетворяться у важливий компонент загальної культури людини та вплинуть на формування здорового способу життя суспільства загалом. Саме в дошкільному віці закладають майбутній потенціал здоров'я, фундамент для формування надалі навичок здорового способу життя.

Основним виховним чинником та першою школою життя для дитини, важливою соціально-педагогічною та захисною силою є сім'я. Формування оздоровчого світогляду, здоров'язбережувальної поведінки відбувається, насамперед, у родині. I вагомими тут стають особистісні ідеали, вподобання, мотиви, інтереси та життєві звички, від яких значною мірою залежать якісні й кількісні показники здоров'я. Слід пам'ятати, що поведінка дорослих є прикладом для наслідування дітьми. I якщо дорослі пропагують здоровий спосіб життя, власним прикладом навчають дітей правилам здоров'язбереження, діти сприйматимуть таку поведінку як єдиноправильну.

Першочерговим завданням $\epsilon$ виховання в дітей потреби в здоров'ї як життєво важливої цінності, свідомого прагнення до дотримання здорового способу життя та формування валеологічної культури особистості.

Передусім слід усвідомити, що без здоров'я людина не може бути щасливою, повноцінно жити, спілкуватися та взаємодіяти з оточуючими, а від того, як вона вміє зберегти своє здоров'я, залежить і їі найближче майбутнє, і якість життя в старості, і його тривалість загалом.

Невтішні дані про захворюваність дітей, небажання, а іноді невміння i дорослих, i малюків керувати власним здоров'ям спонукають науковців до пошуку нових підходів до формування основ здорового способу життя ще 3 раннього дитинства. Дошкільне дитинство $\epsilon$ сприятливим періодом для оволодіння знаннями й навичками формування, збереження та зміцнення здоров'я, які згодом перетворяться у важливий компонент загальної культури людини та 
вплинуть на формування здорового способу життя особистості та суспільства загалом.

Саме в дошкільному віці закладається майбутній потенціал здоров'я, а формування основ здорового способу життя дітей 3-6 років забезпечить підгрунтя для утвердження здоров'язбережувальної поведінки як обов’язкової норми.

Основою формування навичок здорового способу життя дошкільників стануть знання про будову тіла, засоби збереження та зміцнення здоров'я людини, необхідність дбайливого ставлення до власного здоров’я шляхом їхнього усвідомлення за дотримання таких умов:

- відповідність індивідуальним та віковим можливостям дітей;

- вибір найдоцільніших форм, методів та прийомів організації пізнавальної діяльності та забезпечення науково достовірних знань;

- застосування комплексу педагогічних засобів задля засвоєння дошкільниками знань про основи здоров'я, формування позитивної мотивації до вибору здорового способу життя;

- поєднання пізнавальної та практичної діяльності, що забезпечує формування основ здорового способу життя.

Формуванню основ здорового способу життя дітей дошкільного віку сприяють відповідна поведінка дорослих з їхнього найближчого оточення, додержання необхідних санітарно-гігієнічних умов у закладі дошкільної освіти й сім'ї, взаємодія вихователів і батьків з означеної проблеми.

Перший етап неперервної валеологічної освіти людини має забезпечити реалізацію таких завдань: виховання в дітей свідомості того, що людина - частина природи і суспільства; встановлення гармонійних відносин дітей 3 живою та неживою природою; формування особистості дитини; виховання навичок особистої гігієни; гартування дитини та їі рухова активність; профілактика та усунення шкідливих звичок; здійснення валеологічного моніторингу.

Формування основ здорового способу життя вимагає осмислення себе як представника біологічного виду, здатного до оцінки фізичного стану, прогнозування власного здоров'я, його збереження i формування; забезпечення соціальної та психологічної захищеності, душевного комфорту, життєрадісного світосприймання, високих моральних та естетичних почуттів, вміння знаходити задоволення в творчій діяльності; адаптації до соціальних умов, високого рівня культури спілкування і комунікативних навичок.

Слід пам'ятати, що лише єдність вимог щодо способу життя в родині й закладі дошкільної освіти сприятиме формуванню в дитини свідомого ставлення до власного здоров'я, а, відтак, родина може 120 
сприяти поглибленню знань дитини про власне тіло, догляд за ним та шляхи зміцнення здоров'я, а може, навпаки, мати негативний вплив на формування основ здорового способу життя малюка через несвідому позицію відносно здоров'я власного і своєї дитини батька чи матері, а іноді й обидвох батьків, які не мають серед своїх життєвих пріоритетів цінність здоров'я.

\section{Література:}

1. Бєлєнька Г. Здоров'я дитини - від родини // Бєлєнька Г.В., Богініч О.Л., Машовець М.А., 2006. - 220 с.

2. Богініч О. Пріоритети у сфері фізичного розвитку дитини дошкільного віку / Ольга Богініч // Оптимізація фізичного розвитку дитини у вітчизняній системі освіти : монографія / Е. Вільчковський, Н. Денисенко, А. Цьось та ін. - Запоріжжя : ЗОІППО, 2010. - С. 124-148.

3. Вільчковський Е.С. Організація рухового режиму дітей у дошкільних навчальних закладах : навч.-метод. посіб. / Е.С. Вільчковський, Н.Ф. Денисенко. - Тернопіль : Мандрівець, 2008. - 128 с.

4. Лохвицька Л. В. Дошкільникам про основи здоров'я : навч.метод. посіб. / Л.В. Лохвицька, Т.К. Андрющенко. - Черкаси: Відлунняплюс, 2004. - 208 с. 